Rafał Kosiński (Białystok)

\title{
The Exiled Bishops of Constantinople From the Fourth to The LAte Sixth Century
}

$\mathrm{T}$ The existence of quick and efficient communication with the provincial territories was a matter of vital importance to Late-Antique Constantinople, the capital city and the administrative centre of the Eastern Roman Empire. As a result, it became necessary to ensure the creation and maintenance of the land and sea routes linking the City with the provinces. The present article aims to examine which of those links, specifically by land or sea, facilitated a more rapid and convenient communication between the capital city and the more or less distant regions of the Empire, as exemplified by the various places of exile connected with the deposed bishops of Constantinople. Assuming that one of the key goals of sending someone into banishment would be to prevent them, as much as possible, from having any form of communication with the City, the location of the places to which they had been confined by the order of the authorities could indicate which method of contact would have potentially made it easier, or more difficult, for an exiled bishop to communicate with his followers at the capital ${ }^{1}$.

In the early Byzantine period, the office of the Bishop of Constantinople was not a very secure position. Considering the time frame from the consecration of the City until the end of the sixth century, as many as 11 metropolitan bishops, in effect every third one, had been deposed from their office. In a majority of the cases in question, the reasons would be clearly religious, but in several instances various political considerations may have also played a crucial role. This article makes an attempt to focus on the places to which the deposed bishops were banished (actually, if the penalty of exile had been enforced at all) rather than to discuss the causes for the depositions in greater detail. It is important to draw a distinction between removing a bishop from his office (as a rule, according to the canonical procedure, on the strength of a synodal decision) and the emperor's

\footnotetext{
${ }^{1}$ On exiled bishops in Late Antiquity see E. Fournier, Exiled Bishops in the Christian Empire: Victims of Imperial Violence?, [in:] Violence in Late Antiquity: Perception and Practices, ed. H. Drake, Aldershot 2006, p. 157-166, and J. Hillner, Prison, Punishment and Penance in Late Antiquity, Cambridge 2015, especially p. 194-274.
} 
sentence ${ }^{2}$ that condemned the patriarch to leave the City and sometimes also had him sent into exile at a specific location.

The first metropolitan to have been exiled in the period under consideration was Paul, who was deposed from his office three or four times ${ }^{3}$. He was a native of Thessalonica; before his elevation to Archbishop of Constantinople, he served as a lector of the local Church and secretary to Bishop Alexander. After the death of the latter, Paul became his successor in ca. $337^{4}$. The election was not consulted with the imperial authority, which incensed the emperor Constantius II and would effectively lead to the bishop's deposition for the first time and his replacement by Eusebius of Nicomedia ${ }^{5}$. Following Eusebius' death, Paul regained his see, but his return would meet with the Arians' discontent, ultimately resulting in the outbreak of violent riots and the death of magister equitum Hermogenes. ${ }^{6}$. It provided the emperor with a pretext to remove Paul from the See of Constantinople for another time in 342. However, the bishop managed to secure the support from Pope Julius and emperor Constans, who would exert pressure on Constantius to reinstate $\mathrm{him}^{7}$. In early 350, after Constans' death, Paul was accused of taking part in the

\footnotetext{
${ }^{2}$ On exile as a form of punishment, cf. I. Milewski, Depozycje i zsyłki biskupów w Cesarstwie Wschodniorzymskim (lata 325-451), Gdańsk 2008, p. 279-286 and R. Delmaire, Exil, rélegation, déportation dans la législation du bas-empire, [in:] Exil et rélegation. Les tribulations du sage et du saint durant l'antiquité romaine et chrétienne (I-IVe s. ap. J.-C.), ed. Ph. Blaudeau, Paris 2008, p. 115-132.

${ }^{3}$ Socrates, Kirchengeschichte, II, 6-7, 13, 16, 26, ed. G.Ch. Hansen, coop. M. Širinjan, Berlin 1995 (cetera: Socrates, Historia ecclesiastica), p. 96-97, 104-105, 107-108, 135; Sozomenus, Kirchengeschichte, III, 3-5, 7, 9; IV, 2, ed. J. Bidez, rec. G.Ch. HANsen, Berlin 1960 (cetera : Sozomen, Historia ecclesiastica), p. 104-106, 109-110, 112, 140-141; Theodoros Anagnostes, Kirchengeschichte, 57, 84, ed. G.Ch. Hansen, Berlin 1971 (cetera: Theodore Lector, Epitome), p. 29, 41; Theophanis Chronographia, AM 5849, rec. C. DE Boor, vol. I, Lipsiae 1883 (cetera: Theophanes), p. 42. According to I. Milewski, op. cit., p. 356-357, Paul was deposed four times: in 337, 341, 342/343, and $350 / 351$, respectively. However, the traditional historiography mentions no more than three exiles $(339,342,351)$, cf. M. Simonetti, La crisi ariana nel IV secolo, Roma 1975, p. 132-133, an. 104. On Paul, see W. TAFler, Paul of Constantinople, HTR 43, 1950, p. 30-92; G. DAgron, Naissance d'une capitale, Constantinople et ses institutions de 330 à 451, Paris 1974, p. 425-435 and D. Spycha£A, Saint Paul et Macedonius ou la lutte pour le thrône de l'évêque de Constantinople sous le règne de Constance II, [in:] Studia Lesco Mrozewicz ab amicis et discipulis dedicata, ed. S. RuciŃski, C. BALBuzA, Ch. KrólCzyK, Poznań 2011, p. 377-390.

${ }^{4}$ The date of the inauguration of Paul's episcopate remains a subject of scholarly debate, cf. I. MiLewSKI, op. cit., p. 131.

${ }^{5}$ On Eusebius, see C. LuibheId, The Arianism of Eusebius of Nikomedia, ITQ 43, 1976, p. 3-23.

${ }^{6}$ On Hermogenes, see PLRE, I, p. 422-423 (s.v. Hermogenes 1). For an account of those events, cf. P. FilipCZaK, Bunty i niepokoje w miastach wczesnego Bizancjum (IV wiek n.e.), Łódź 2009, p. 123-124 and M.B. Leszka, Kościół i jego wplyw na życie mieszkańców Konstantynopola, [in:] Konstantynopol Nowy Rzym. Miasto i ludzie w okresie wczesnobizantyńskim, ed. M.J. LeszKa, T. WolıńsKa, Warszawa 2011, p. 357-358.

${ }^{7}$ Socrates, Historia ecclesiastica, II, 22, p. 123; Sozomen, Historia ecclesiastica, III, 20, p. 133-134. Cf. M. Simonetti, op. cit., p. 188, an. 41.
} 
revolt of Magnentius ${ }^{8}$ and eventually banished from the capital. He died in exile sometime in the following year.

During his first exile (ca. 337), Paul was expelled to an unspecified location, but his subsequent presence in Rome would imply that he must have left that place 9 Later on, in 342, as Athanasius of Alexandria recounts ${ }^{10}$, the bishop was sent into exile at Singara in Mesopotamia ${ }^{11}$, and then at Emesa ${ }^{12}$, but he would leave his place of exile again ${ }^{13}$. In 344 , he was banished to Thessalonica ${ }^{14}$, yet he escaped once again and returned to Italy. Finally, in 351, after the death of Constans, Constantius II ordered Paul's banishment for the last time: the bishop was deported to Cocusus ${ }^{15}$ in Cappadocia, where he died ${ }^{16}$.

His successor was Macedonius, Bishop of Constantinople from 342 to 346 and then again from 351 to 360 . He was elevated to the See of Constantinople for the

${ }^{8}$ On Magnentius' revolt, cf. J.F. DRINKwater, The revolt and ethnic origin of the usurper Magnentius (350-53) and the rebellion of Vetranio (350), Chi 30, 2000, p. 131-159.

${ }^{9}$ Theodoret, Kirchengeschichte, II, 5, ed. L. Parmentier, rec. F. Scheidweiler, Berlin 1954 (cetera: Theodoret, Historia ecclesiastica), p. 99; Sozomen, Historia ecclesiastica, III, 7-8, p. 109-111.

10 Athanasius, Historia Arianorum, 7, 3, [in:] Athanasius, Werke, vol. II.1, Die Apologien, ed. H.G. Opitz, Berlin-Leipzig 1935-1941, p. 186. According to Timothy Barnes, the emperor only ordered him to leave Constantinople. The bishop went to the court of Constans at Trier; cf. T.D. Barnes, Athanasius and Constantius. Theology and Politics in the Constantinian Empire, Cambridge 1993, p. 212-214.

${ }^{11}$ Singara (modern-day Balad Sinjar in north-western Iraq) was a stronghold in the north of Mesopotamia, which constituted an important element of the Roman Empire's defence system along the Roman-Persian frontier; cf. F.H. Weissbach, Singara, [in:] RE, s. II, vol. III, Stuttgart 1927, col. 232-233. D. OAtes, Studies in the Ancient History of Northern Iraq, Oxford 1968, p. 100-106 and D. van Berchem, Recherches sur la chronologie de Syrie et de Mésopotamie, Sy 31, 1954, p. 265-267.

${ }^{12}$ Emesa (present-day Homs in Syria), a city in the province Phoenicia Libanensis, located at the junction of the routes from Palmyra to the Mediterranean and from Damascus to the north; a significant pilgrimage site following the discovery of John the Baptist's head at a local monastery in 453, later on to be housed at the cathedral church of this city; cf. I. Benzinger, Emesa, [in:] RE, vol. V, Stuttgart 1905, col. 2496-2497 and M. MANGo, Emesa, [in:] ODB, p. 690.

${ }^{13}$ G. Dagron, Naissance d une capitale, p. 430-432 suggests that the destination of Paul's exile may have been Thessalonica, not the East, and puts the date of this event to the year 338/339.

${ }^{14}$ Socrates, Historia ecclesiastica, II, 16, p. 108; Sozomen, Historia ecclesiastica, III, 9, p. 111-112; Theophanes, AM 5849, p. 42.

${ }^{15}$ Cocusus (Kokousos, present-day Göksun, Turkey), a city in Cappadocia (subsequently in Armenia II), situated at the intersection of the routes from Caesarea to Anazarbus and from Comana to Melitene, near the sources of the river Pyramus, cf. Ruge, Kokusos, [in:] RE, vol. VI, Stuttgart 1921, col. 1065. G. DAGron, op. cit., p. 427, notes that the information on Paulus' final exile can be found in Athanasius' account, which identifies Singara and Emesa as the actual locations of the bishop's exile.

${ }^{16}$ Socrates, Historia ecclesiastica, II, 26, p. 135; Sozomen, Historia ecclesiastica, III, 9, p. 111-112 and IV, 2, p. 140-141. Athanasius, Historia Arianorum, 7, 3, p. 186. Cf. M. Simonetti, op. cit., p. 214-215; D. Spycha£A, Saint Paul et Macedonius..., p. 386; IDEM, Cesarze rzymscy a arianizm od Konstantyna Wielkiego do Teodozjusza Wielkiego (312-395), Poznań 2007, p. 109; J. Hillner, Confined Exiles: An Aspect of the Late Antique Prison System, Mil 10, 2013, p. 419-420. 
first time upon the aforementioned deposition of Paul. Since the latter bishop had managed to obtain firm support from Constans, Constantius II was compelled to restore him to the see, while Macedonius was ousted and had to withdraw to a private church. Following the death of Constans, the bishop recovered his office ${ }^{17}$, but he would begin to lose the emperor's support in 358 , when he decided to remove the remains of Constantine the Great from the dilapidated tomb and re-bury the emperor's body in a new place. Constantius reacted with indignation to Macedonius' decision to translate the remains of the emperor's father without any previous consultation ${ }^{18}$. The synod of Constantinople, which was summoned at the turn of 359 and 360 by Constantius II, condemned the homoiousians and Macedonius would become the most prominent bishop to be deposed. On January 27, 360, he was replaced by the Arian clergyman Eudoxius and banished to his family estate in Bithynia, where he died shortly afterwards ${ }^{19}$.

Evagrius (d. ca. 380) acceded to the See of Constantinople in an atmosphere of violent unrest and strife in $370^{20}$. Previously a Constantinopolitan presbyter, he was consecrated as bishop by the deposed bishop of Antioch Eustathius, which sparked off a wave of violent protests and riots. In response to the situation, the emperor Valens expelled the new bishop to an unidentified location, most probably somewhere in Thrace, several months later, where he would stay until his death ${ }^{21}$.

The last metropolitan bishop to have been exiled in the fourth century and at the same time the last one involved in the Arian controversy was Demophilus. He became Archbishop of Constantinople in April 370 and remained in office for about a decade, even though his episcopate is not very well documented in the sources $^{22}$. His election brought on a violent backlash, resulting in disturbances

\footnotetext{
${ }^{17}$ Socrates, Historia ecclesiastica, II, 26-27, p. 136-137; Sozomen, Historia ecclesiastica, IV, 2, p. 141. Cf. G. Dagron, Naissance d' une capitale, p. 432; M.B. LeszKa, op. cit., p. 357-359.

${ }^{18}$ Socrates, Historia ecclesiastica, II, 38, p. 167-168; Sozomen, Historia ecclesiastica, IV, 21, p. 171.

${ }^{19}$ Sozomen, Historia ecclesiastica, IV, 26, p. 182. Cf. I. Milewski, op. cit., p. 358; G. Dagron, op. cit., p. 436-442.

${ }^{20}$ Socrates, Historia ecclesiastica, IV, 14, p. 244; Sozomen, Historia ecclesiastica, VI, 13, p. 254-255. Cf. G. DAGRon, op. cit., p. 446.

${ }^{21}$ Socrates, Historia ecclesiastica, IV, 15, p. 244. Socrates' account is not clear as regards the information to the effect that the emperor had Eustathius exiled to Bizye in Thrace, whereas Evagrius

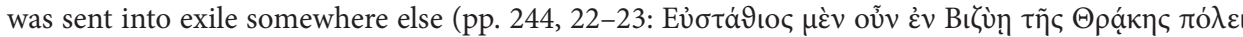

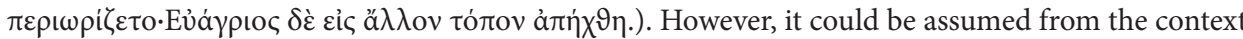
that the location in question may have been somewhere in Thrace as well. The same information, as drawn from Socrates' account, can be found in Sozomen, Historia ecclesiastica, VI, 13, p. 255, 1-3. ${ }^{22}$ Socrates, Historia ecclesiastica, IV, 14, p. 244 and V, 7, p. 278; Sozomen, Historia ecclesiastica, VI, 13, p. 254 and VII, 5, p. 306-307; Philostorgius, Kirchengeschichte. Mit dem Leben des Lucian von Antiochien und den Fragmenten des arianischen Historiographen, IX, 8, 10, 13, 14, 19, ed. J. BIDEZ, bearbeitete Auflage von F. Winkelmann, Berlin 1981(cetera: Philostorgius, Historia ecclesiastica), p. 119-122, 125. Cf. G. DAGron, op. cit., p. 446-450.
} 
and new divisions in the Church of Constantinople. In consequence, the supporters of the Nicene Creed proceeded with the election of their own candidate (Evagrius). None the less, Demophilus managed to secure the crucial support of the emperor Valens, and the outcome was the eventual exile of the pro-Nicene contender. The turning point would come on 24 November 380, when the emperor Theodosius I, a dedicated advocate of the Council of Nicaea, arrived at the capital, and the situation put Demophilus in danger of losing his bishopric. The emperor pledged to allow him to remain in office on the condition of adopting the Nicene Creed, but Demophilus declined and withdrew with his followers to a church outside of the city walls ${ }^{23}$. According to Philostorgius' account ${ }^{24}$, Demophilus left for Berroia $^{25}$ in Thrace, his previous see ${ }^{26}$. It is difficult to determine when Demophilus' exile might have taken place, as he still would have been present at the synod of Constantinople in 383, representing the Constantinopolitan Arian faction ${ }^{27}$.

One of the best known bishops banished from Constantinople is John Chrysostom $^{28}$. Born at Antioch, he was educated in rhetoric and practised asceticism. After several years spent in the desert, he returned to his native city and was ordained a priest there, becoming an eminent preacher. He was elected to the See of Constantinople in the autumn of 397, but he would soon find himself at odds with many influential circles and figures at the capital, including emperor Arcadius' wife, Aelia Eudoxia. In July 403, during the so-called synod of the Oak (east of the Bosphorus), he was deposed by the bishops led by Patriarch Theophilus of Alexandria $^{29}$. To enforce the synod's verdict, the authorities banished John to Prainetus,

${ }^{23}$ Socrates, Historia ecclesiastica, V, 7, p. 278; Sozomen, Historia ecclesiastica, VII, 5, p. 306-307; CTh XVI, 5, 6. I. Milewski, op. cit., p. 210.

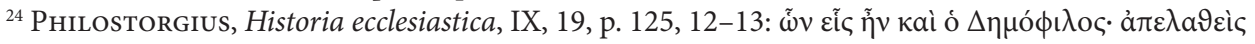

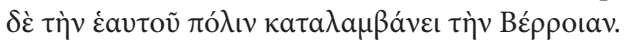

${ }^{25}$ Berroia (Beroa, modern-day Veria in northern Greece) - a city at the foot of Mount Bermius in the province of Macedonia I, $73 \mathrm{~km}$ south-west of Thessalonica, cf. E. OBerhummer, Beroia, [in:] RE, vol. III, Stuttgart 1897, col. 304-306.

${ }^{26}$ Philostorgius, Historia ecclesiastica, IX, 8, p. 119.

${ }^{27}$ Socrates, Historia ecclesiastica, V, 10, p. 284; Sozomen, Historia ecclesiastica, VII, 12, p. 315-316.

${ }^{28}$ There is an extensive amount of scholarly literature on John Chrysostom. It is worth mentioning the following two monographs: Ch. BAUR, Der heilige Johannes Chrysostomus und seine Zeit, vol. I-II, München 1929-1930 (still the fundamental work concerning this figure) and J.N.D. KelLY, Golden Mouth. The Story of John Chrysostom. Ascetic, Preacher, Bishop, New York 1995. On his Constantinopolitan period see C. Tiersch, Johannes Chrysostomus in Konstantinopel (398-404). Weltsicht und Wirken eines Bischofs in der Hauptstadt des Oströmischen Reiches, Tübingen 2002.

${ }^{29}$ Palladios, Dialogue sur la vie de Jean Chrysostome, 8, ed. A.-M. Malingrey, Ph. Leclerce, vol. I, Paris 1988 (cetera: Palladius, Dialogus de vita s. Joannis Chrysostomi), p. 230; Рнотіus, Bibliothéque, 59, trans. et ed. R. Henry, vol. I, Paris 1959 (cetera: Photius, Bibliotheca), p. 52-57; Socrates, Historia ecclesiastica, VI, 15, p. 336-338; Sozomen, Historia ecclesiastica, VIII, 17, p. 371-373. Cf. I. Milewski, op. cit., p. 151-154; J.N.D. Kelly, op. cit., p. 211-227. 
a town between Helenopolis and Nicomedia, not very far from the capital ${ }^{30}$. It was likely to be the first stage of John's exile, but the final destination remains unknown since the original decision had been changed. Subsequently, on 20 June 404, John was moved to Nicomedia, then to Nicaea, and finally to Cocusus ${ }^{31}$. In mid-summer 407, the emperor's edict ordered an immediate expulsion of John to Pityus ${ }^{32}$ on the east coast of the Black Sea. He died on his journey to that location ${ }^{33}$.

Nestorius was another famous church figure condemned to exile ${ }^{34}$. Like John Chrysostom, he was a native of Antioch and was elevated to Patriarch of Constantinople at the emperor's behest. His consecration took place on 10 April $428^{35}$. The new bishop would soon become embroiled in a conflict with the powerful elites of the City and, later on, with Patriarch Cyril of Alexandria over a Christological controversy. The latter dispute came to a critical point on 22 June 431, when Nestorius was deposed by the Cyrillian faction at the Council of Ephesus ${ }^{36}$. It did not mean, however, that the deposition would be carried through immediately, as Nestorius still enjoyed the emperor's support. Ultimately, the increasing pressure exerted by the Constantinopolitan monastic circles induced the emperor to agree to his deposition and to put him, as well as the other deposed bishops, Cyril of Alexandria and Memnon of Ephesus (both of them adversaries of Nestorius), in custody ${ }^{37}$. On September 4, 431, after Nestorius' repeated requests, the emperor agreed to his departure from Ephesus and return to the monastery of Euprepius at Antioch ${ }^{38}$. It is notable that Nestorius was allowed to return to that monastery

\footnotetext{
${ }^{30}$ Socrates, Historia ecclesiastica, VI, 16, p. 338-339; Sozomen, Historia ecclesiastica, VIII, 18, p. 373-374.

${ }^{31}$ Palladius, Dialogus de vita s. Joannis Chrysostomi, 3, p. 39, 11, p. 14-17; Sozomen, Historia ecclesiastica, VIII, 22, p. 379; Theodoret, Historia ecclesiastica, V, 34, p. 335.

${ }^{32}$ Pityus was situated on the east coast of the Black Sea, about $75 \mathrm{~km}$ north-west of Suchumi in Abkhazia, over $1,100 \mathrm{~km}$, by sea route, from Constantinople, cf. E. DieHL, Pityus, [in:] RE, vol. XX, Stuttgart 1950, col. 1883-1884.

${ }^{33}$ Palladios, Dialogus de vita s. Joannis Chrysostomi, 11, p. 120-156; Socrates, Historia ecclesiastica, VI, 21, p. 344-345; Sozomen, Historia ecclesiastica, VIII, 28, p. 389; Theodoret, Historia ecclesiastica, V, 34, p. 335-336. Cf. J.N.D. KeLlY, op. cit., p. 272-285.

${ }^{34}$ On the life of Nestorius, cf. R. Kosıńsкi, Dzieje Nestoriusza, biskupa Konstantynopola $w$ latach 428-431, [in:] U schyłku starożytności. Studia źródłoznawcze, vol. VII, ed. P. JANIszewsKi, R. WIŚNIEWSKI, Warszawa 2008, p. 30-63.

${ }^{35}$ Socrates, Historia ecclesiastica, VII, 29, p. 377-378; La seconde partie de l'histoire de Barhadbešabba 'Arbaïa et controverse de Théodore de Mopsueste avec les macédoniens, 20-21, ed. et trans. F. NAU, PO 9, Paris 1913 (cetera: BARHAdBesabba of ArbaÏA, Historia ecclesiastica), p. 521, 529-531.

${ }^{36}$ ACO, vol. I, 1, 2, p. 54-64, cf. A. DE Halleux, La première session du concile d’Éphèse (22 juin 431), ETL 69, 1993, p. 79-81.

${ }^{37}$ Nestorius, Le livre d'Héraclide de Damas, ed. P. Bedjan, Paris 1910 (cetera: Nestorius, Liber Heraclides), p. 374-384.

${ }^{38}$ ACO, vol. I, 1, 7, p. 71, also Nestorius, Liber Heraclides, p. 387; Nestoriana. Die Fragmente des Nestorius, ed. F. Loofs, Halle 1905, p. 194, Barhadbesabba of ArbaÏA, Historia ecclesiastica, 25, p. 555-556.
} 
as a free $\operatorname{man}^{39}$. Despite the fact of the consecration of a new archbishop, a majority of the bishops from the East would continue to refuse to anathematize Nestorius and to accept his deposition until as late as $433^{40}$. However, Bishop Maximian died in April 434 and rumours appeared that Nestorius could be possibly restored to his former office ${ }^{41}$. It became clear to the court that the situation would continue to be volatile as long as Nestorius, still at Antioch, could have any influence on the affairs of the Church. On 3 August 435, the emperor issued a constitution aimed against the supporters of Nestorius ${ }^{42}$. The bishop was divested of his property and sent into exile at Petra ${ }^{43}$. The date remains controversial, but it is very likely that it may have happened sometime in the latter half of the year $435^{44}$. Nevertheless, Petra was not to become a final destination of his exile as it seems that not very long after his first banishment, still in the late 430s, he was moved to the Great Oasis in Egypt ${ }^{45}$ and perhaps placed at one of the monasteries there, where he would live until his death ${ }^{46}$.

Flavian served as Bishop of Constantinople from 446 to 449. The Council of Ephesus, convened on 8 August 449 with the purpose of investigating the Eutychian dispute, rehabilitated the controversial Constantinopolitan monk and carried through a deposition of Flavian, who had been responsible for having Eutyches banished in the previous year ${ }^{47}$. The bishop feared for his life and decided to seek refuge inside the church at Ephesus. He was prevented from entering the church but he managed to find asylum in the sacristy ${ }^{48}$. Ultimately, he was banished to and died at Hypaipa in Lydia ${ }^{49}$, yet the dates of his exile and death remain disputable.

\footnotetext{
${ }^{39}$ Cf. G.A. Bevan, The Last Days of Nestorius in the Syriac Sources, JCSSS 7, 2007, p. 40. A different, but incorrect, opinion can be found in, e.g., J. McGuckin, Saint Cyril of Alexandria and the Christological Controversy. Its History, Theology, and Texts, New York 2004, p. 106, who notes that the emperor had also condemned Nestorius to exile.

${ }^{40}$ ACO, vol. I, 1, 7, p. 164-165.

${ }^{41}$ ACO, vol. I, 4, p. 170 and Callinicos, Vie d Hypatios, 39. 1, ed. et trans. G.J.M. Bartelink, Paris 1971 (cetera: Kallinikos, Vita Hypatii), p. 232.

${ }^{42}$ CTh XVI, 5, 66 and CJ I, 5, 6. Cf. also the Greek text in the ACO, vol. I, 1, 3, p. 68.

${ }^{43}$ ACO, vol. I, 1, 3, p. 67 and ACO, vol. I, 4, p. 66. In Nestorius' lifetime, Petra formed part of the Palaestina Tertia, and was the capital of that province, cf. W.E. KAegi, A. KAZHDAn, Petra, [in:] ODB, p. 1642-1643. ${ }^{44}$ For a detailed discussion of the difficulties over the dating of Nestorius' exile, see G.A. Bevan, The Case of Nestorius: Ecclesiastical Politics in the East, 428-451 CE, Toronto 2005 [PhD diss.], p. 274-278. ${ }^{45}$ The Great Oasis (present-day Khargêh) is situated in the Libyan Desert in Egypt, ca. 200 km west of the Nile, cf. J. BALL, Khargah Oasis. Its Topography and Geology, Cairo 1900.

${ }^{46}$ In the light of a fragment of Nestorius' letter addressed to the governor of Thebaid, the former bishop would live at a place known as Oasis of Ibis, cf. The Ecclesiastical History of Evagrius with the scholia, I, 7, ed. J. Bidez, L. Parmentier, London 1898 (cetera: Evagrius, Historia ecclesiastica), p. 14, 25 and 15, 23.

${ }^{47}$ ACO, vol. II, 1, 1, p. 191.

${ }^{48}$ ACO, vol. II, 2, p. 78.

${ }^{49}$ Nestorius, Liber Heraclides, p. 494-495; Liberatus XII, 75, [in:] ACO, t. II, Concilium Universale Chalcedonense, vol. V, Collectio sangermanensis, ed. E. Schwartz, Berolini et Lipsiae 1936, p. 118; The Chronicle of Marcellinus, s.a. 449, trans. B. Croke, Sydney 1995 (cetera: MArCellinus Comes),
} 
Some scholars are of the opinion that contrary to the generally accepted account of Flavian's death on 11 August 449 in the aftermath of a brutal treatment during the council and following his deposition, he died in February $450^{50}$.

For almost half a century after Flavian's exile, the bishops of Constantinople would be able to remain in office until their death. In one noteworthy case, Basiliscus made an attempt to remove Patriarch Acacius, but the bishop resisted and managed to save his position thanks to the crucial support from the monastic circles and the people of Constantinople ${ }^{51}$. This failure on the emperor's part seems to be indicative of the fact that throughout the decades the position of bishops of Constantinople had become consolidated enough to make it more difficult to have them deposed from the metropolitan see. It was only in the late fifth century that bishop Euphemius was removed from office ${ }^{52}$. A native of Apamea, he became a presbyter entrusted with providing charitable services for the poor in the Church of Constantinople ${ }^{53}$. Euphemius succeeded Patriarch Fravitta, who died in March $490^{54}$. His unwavering dedication to the decrees of Chalcedon was very well known but it was the weight of political issues, not any particular doctrinal disagreement, that would lead to his conflict with emperor Anastasius, eventually resulting in the deposition of the bishop in $496^{55}$. Anastasius came to suspect or even obtained some evidence for Euphemius' alleged collaboration with Isaurians, bringing on

p. 19: in Epipam exulatus est. Cf. H. СнаDwicк, The Exile and Death of Flavian of Constantinople. A Prologue to the Council of Chalcedon, JTS 6, 1955, p. 19-20; K. ILSKI, Sobory w polityce religijnej Teodozjusza II, Poznań 1992, p. 22-23, an. 71; cf. I. Milewski, op. cit., p. 362. Hypaipa was a city and bishopric in Lydia, on the route from Ephesus to Sardes, at the foot of the mountain called Aipus, cf. BürCHNer, Hypaipa, [in:] RE, vol. VIII, Stuttgart 1914, col. 195-196.

${ }^{50}$ Cf. E. Schwartz, Publizistische Sammlungen zum acacianischen Schisma, München 1934, p. 174, an. 3; this scholar arrived at the conclusion that Flavian died in February 450. Initially, this proposition elicited no response and would be thoroughly considered by Chadwick (cf. H. CHADwick, op. cit., p. 19-34), who, although refuting Schwartz's argumentation, would appear to have been in favour of this particular dating of Flavian's death and contributed some new points to support it. ${ }^{51}$ For Acacius and his conflict with Basiliscus, see R. Kosıński, Dzieje Akacjusza, patriarchy Konstantynopola w latach 471-489, USS 9, 2010, p. 63-97.

${ }^{52}$ On Euphemius, see R. Kosıński, Euphemios, Patriarch of Constantinople in the Years 490-496, JÖB 62, 2012, p. 57-79.

${ }^{53}$ Historia Ecclesiastica Zachariae Rhetori vulgo adscripta, VI, 4, rec. E.W. Brooks, vol. II, Lovanii 1924 (cetera: Pseudo-Zacharias, Historia ecclesiastica), p. 5-6; Theophanes, AM 5981, p. 133. According to Pseudo-Zacharias, Euphemius received his education in Alexandria. Conversely, Liberatus mentions Alexandria as his birth-place, which is very likely a confusion arising from his misinterpretation of facts from Pseudo-Zacharias' account (cf. Liberatus, XVIII, 127, p. 132). ${ }^{54}$ Theodore Lector, Epitome 440, p. 122. On the other hand, Evagrius, Historia ecclesiastica, III, 23, p. 121 refers to four months of Fravitta's episcopate. Cf. E. Schwartz, op. cit., p. 213, esp. an. 2; PH. Blaudeau, Alexandrie et Constantinople (451-491). De l'histoire à la géo-ecclésiologie, Roma 2006, p. 234.

${ }^{55}$ On the disputed date of his deposition, see R. Kosıński, Euphemios..., p. 75, note 123. 
the deposition and banishment of the disloyal bishop ${ }^{56}$, first to Euchaïta ${ }^{57}$, later on to Ancyra ${ }^{58}$, where he died in 515.

A similar fate would befall his successor, Macedonius $\mathrm{II}^{59}$. He was a nephew of Gennadius (Patriarch of Constantinople in the years 458-471) ${ }^{60}$ and a follower of the Council of Chalcedon. Contrary to his predecessor, he was more inclined to make a compromise with the anti-Chalcedon Patriarch of Alexandria on the basis of the emperor Zeno's Henotikon. He managed to find allies at the court and would meet with much success in the East, where a majority of the Churches decided to endorse that compromise solution ${ }^{61}$. Beginning from 507, a hiatus between the emperor and the bishop was growing more and more difficult to repair, which was the situation caused by Anastasius' increasingly evident anti-Chalcedonian sympathies. In 511, Macedonius became embroiled in an intense controversy with the advocates of Miaphysitism, Julian of Halicarnassus and Severus, the later bishop of Antioch ${ }^{62}$. On the night of 6-7 August 511, he was banished to Euchaïta in Pontus on the emperor's orders ${ }^{63}$ and died at Gangra ca. $517^{64}$.

${ }_{56}$ Theodore Lector, Epitome 449, 455, p. 126-127, 128; Theophanes, AM 5987, p. 139; Georgii Monachi Chronicon, ed. C. DE Boor, vol. II, Textum genuinum inde a Vespasiani imperio continens, Lipsiae 1904 (cetera: George the Monk), p. 623-624; The Synodicon Vetus, 109, ed. et trans. J. Duffy, J. PARKer, Washington 1979 (cetera: Synodicon Vetus), p. 92; Evagrius, Historia ecclesiastica, III, 30, p. 126-127; Marcellinus Comes, s.a. 495, p. 31.

${ }^{57}$ Theodore Lector, Epitome 457, p. 128 = George the Monk, p. 625; Theophanes, AM 5989, p. 140. Euchaïta, a place of exile for several figures of note, was located in Pontus, west of Amasea; it was made a city by emperor Anastasius, cf. H. GrÉGOIRE, Géographie byzantine, BZ 19, 1913, p. 59-61 and C. Foss, Euchaita, [in:] ODB, p. 737.

${ }^{58}$ The information on Ancyra as Euphemios' place of exile and the year 515 as the date of his death can be found in only one source: VitTore da Tunnuna, Chronica. Chiesa e impero nell' età di Giustiniano, s.a. 515.2, ed. A. Placanica, Firenze 1997 (cetera: Victor of Tunnuna), p. 32. According to Synodicon Vetus 115, p. 96 Euphemius and Macedonius died at Gangra. Ancyra was the administrative centre and the ecclesiastical metropolis of Galatia. It also served as a military base of strategic importance. In the fifth century, it gained in prominence as a place of summer residence preferred by emperors, cf. C. Foss, Ankyra, [in:] ODB, s. 102.

${ }^{59}$ On Macedonius, see W.H.C. Frend, The Fall of Macedonius in 511 - a Suggestion, [in:] Kerygma und Logos. Beiträge zu den geistesgeschichtlichen Beziehungen zwischen Antike und Christentum. Festschrift für Carl Andresen zum 70. Geburtstag, ed. A.M. Ritter, Göttingen 1979, p. 183-195 and

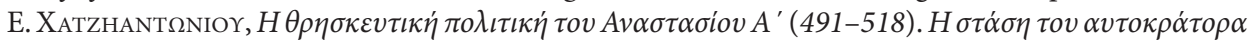

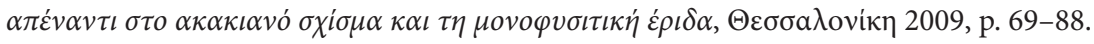

${ }^{60}$ Theodore LeCtor, Epitome 458, p. 129.

${ }^{61}$ Cf. W.H.C. Frend, op. cit., p. 185.

${ }^{62}$ Theodore Lector, Epitome 484, p. 138; Liberatus, XVIII, 134, p. 133; Vie de Sévère par Jean, superieur de monástere de Beith-Aphthonia, ed. M.-A. Kugener, PO 2, Paris 1907, p. 236-237. Cf. F. HaArer, Anastasius I. Politics and Empire in the Late Roman World, Cambridge 2006, p. 145-151.

${ }^{63}$ Evagrius, Historia ecclesiastica, III, 32, p. 130; Victor of Tunnuna, s.a. 501, p. 26; MARCEllinus Comes, s.a. 511, p. 35; Theodore Lector, Epitome 487, p. 138; Pseudo-Zacharias, Historia ecclesiastica, VII, 8, p. 28-33. ${ }^{64}$ Theophanes, AM 6008, p. 161-162. Gangra (present-day Çankırı in Turkey), the capital city of Paphlagonia, is situated on a tributary of the river Halys, at the main route that connects Galatia 
Before his elevation to Patriarch of Constantinople, Anthimus ${ }^{65}$ had served as Bishop of Trebizond, but he deserted his bishopric and decided to practise asceticism in Constantinople ${ }^{66}$. In 532/533, he participated, on the pro-Chalcedonian side, in a dispute with the adherents of Severus of Antioch ${ }^{67}$. Following the death of Patriarch Epiphanius on June 5, 535, Anthimus was chosen as his successor with the decisive support of empress Theodora ${ }^{68}$, but he would very soon arouse suspicion of harbouring Miaphysite views. The monastic circles urged him to condemn Eutyches and Dioscurus of Alexandria, but the bishop refused to do so ${ }^{69}$. In March 536, Pope Agapetus I arrived at Constantinople, refusing to acknowledge communion with Anthimus and accusing him of having assumed the bishopric in violation of the church canons $^{70}$. Justinian wasted no time in removing Anthimus from his office and had the bishop expelled from Constantinople $^{71}$. The synod convoked by the emperor (2, 6, 10, 21 May and 4 June 536; concluded 6 August of the same year) condemned Anthimus for the uncanonical manner of his accession to the See of Constantinople and for his adherence to Eutyches' teachings ${ }^{72}$. On the other hand, John of Ephesus claims that the bishop accepted the empress Theodora's proposal and would go on to spend the next 12 years at her estate in Constantinople, leading an ascetic life. Found there only after the empress' death, he became reconciled with Justinian. The former bishop reportedly enjoyed the emperor's respect for the rest of his life ${ }^{73}$, yet his later years and the date of death remain unknown.

In the sixth century, the authorities carried through only one deposition from the office of metropolitan bishop, removing Eutychius from the See of Constantinople $^{74}$. He was born at a village called Theium (Theion), in Phrygia, and became

with the Black Sea. In the fifth and sixth centuries, Gangra was a place of exile for many important figures of the Church, cf. C. Foss, Gangra, [in:] ODB, p. 821.

${ }^{65}$ E. Honigmann, Anthimus of Trebizond, Patriarch of Constantinople (June 535-March 536), [in:] Patristic Studies, Città del Vaticano 1953, p. 185-193 and A. GrillmeIER in collaboration with Th. HainTHALER, Christ in Christian Tradition, vol. II, From the Council of Chalcedon (451) to Gregory the Great (590-604), part II, The Church of Constantinople in the sixth century, trans. J. CAWTE, P. AlLEN, London 1995, p. 347-355.

${ }^{66}$ ACO, vol. III, p. 131, 134, 139; John of Ephesus, Lives of the Eastern Saints, 48, ed. et trans.

E.W. Brooks, PO 18, Paris 1924 (cetera: John of Ephesus, Lives of the Eastern Saints), p. 685.

${ }^{67}$ ACO, vol. IV, 2, p. 169.

${ }^{68}$ Pseudo-Zacharias, Historia ecclesiastica, IX, 19, p. 93-94.

${ }^{69}$ ACO, vol. III, p. 134, 179.

${ }^{70}$ Liberatus, XXI, 146-147, p. 135-136.

${ }^{71}$ Liberatus, XXIII, 159, p. 138-139. John of Ephesus is incorrect in his information that Anthimus held the Patriarchate of Constantinople for as long as several years (cf. JoHn of EpHEsus, Lives of the Eastern Saints, 48, p. 685).

${ }^{72}$ ACO, vol. III, p. 178-180.

${ }^{73}$ John of Ephesus, Lives of the Eastern Saints 48, p. 687.

${ }^{74}$ Theophanes, AM 6044, p. 228. On Eutychius, see R. Janin, Eutichio, [in:] Bibliotheca Sanctorum, vol. V, Roma 1964, col. 323-324, A. Kazhdan, Eutychios, [in:] ODB, p. 759. Cf. also M. Whitbi, 
a monk in Amaseia at the age of 30. After the death of Patriarch Menas on August 25, 552, Justinian designated Eutychius as successor in connection with the new bishop's embrace of the emperor's policy on the so-called Three Chapters. A year later, the bishop presided over the proceedings of the Second Council of Constantinople, yet he refused to accept the doctrine of aphthartodocetism, which was advocated by Justinian. This act of resistance led to the bishop's arrest and confinement. Arrested on 22 January 565, he was first placed at the Choracudis monastery and, on the following day, at the monastery of St. Osias near Chalcedon. Finally, he was deposed on 31 January after his refusal to appear before a synod summoned by Justinian (the so-called endemousa synod), sent into exile on an island in the Propontis known as Principus (Princes' Island), and subsequently to his former monastery at Amaseia, where he would spend over 12 years $^{75}$.

The cases described above are indicative of the fact that the rulers would always make an effort to remove the deposed bishops from the City, but sometimes without explicit orders to have them confined to a definite place of exile. In the fourth century, the bishops retreated to the suburbs or to their estates, and it was only in the fifth century that depositions from the office of the metropolitan would begin to involve being "deported" to a specific exile location.

The motives behind banishing bishops from the City and putting them in custody at a remote place were obvious. First of all, the exile was intended as a measure preventing the deposed bishop from having any real influence on the community of the faithful in Constantinople; secondly, it was a form of punishment, in particular when the destination was located in some remote region with harsh climate conditions or exposed to various dangers such as the threat of a nomad attack ${ }^{76}$.

As regards the first of the above-mentioned objectives, the places of exile should be viewed from the angle of their accessibility. It appears that throughout the fourth century the authorities did not attach much importance to exile locations, as the banished individuals were frequently placed not very far from the capital (Thessalonica, Thrace, Bithynia). The situation changed in the early fifth century, beginning from John Chrysostom's exile, when destinations would be more deliberately selected. Most of those localities were inland towns/cities, normally situated along the communication routes but at a greater distance from the sea coast (Amaseia, Hypaipa, Ancyra, Euchaita, Emesa), or even off the main routes from and to Constantinople (Cocusus, Petra, Great Oasis, Singara). A rather singular case is Pityus, which would fulfil all the criteria for being a very distant and extremely inaccessible place, although it was located on the Black Sea coast.

Eutychius, Patriarch of Constantinople. An Epic Holy Man, [in:] Homo Viator: Classical Essays for John Bramble, ed. M. Whitby, Ph. Hardie and M. Whitbi, Bristol 1987, p. 297-308.

75 Theophanes, AM 6057, p. 240. Cf. A. Grillmeier in collaboration with Th. Hainthaler, op. cit., p. 469 and 490. Amaseia was situated on the river Lycus in Pontus; the city functioned as the metropolis of the Pontic provinces, cf. C. Foss, Amaseia, [in:] ODB, p. 74.

${ }^{76}$ Cf. I. Milewski, op. cit., p. 353-355. 
Obviously, sending a person into exile at a remote location such as the Great Oasis did not mean there would be no attempts undertaken to communicate with them, provided that those who wished to maintain such contact had resources, especially sufficient amounts of money, at their disposal in order to make a long and dangerous journey (or to cover the costs if a trustworthy person could undertake it). The cases of Nestorius and John Chrysostom prove this point very clearly. For instance, John Chrysostom carried on his extensive correspondence in exile, with about 240 surviving letters addressed to as many as over a hundred figures in Constantinople and beyond. Occasionally, people would visit him at Cocusus, with many of his admirers from Antioch and other places in Syria. Moreover, John had substantial resources at his disposal. In his correspondence, he would also attempt to maintain a semblance of being still in charge of the affairs of his Church. He addressed letters to his presbyters and Gothic monks, showing much interest in the Gothic community living along the north-west coast of the Black Sea, and also exchanged friendly correspondence with some high-profile figures such as prefects of the City Gemellus ${ }^{77}$ (ep. 79, 124, 132, 194) and Paianius ${ }^{78}$ (ep. 95, 193, $204,220)^{79}$. In turn, Nestorius would keep on receiving the news of all the important religious issues and events at the capital; for instance, he knew about the conflict between bishop Flavian and Eutyches as well as the events in connection with the Council of Ephesus in 449. Let us also make a mention of his letter addressed to the citizens of Constantinople in the late $440 \mathrm{~s}^{80}$. Some of Nestorius' followers managed to reach him at his place of exile, but such visits were not as frequent as in the case of John Chrysostom.

In conclusion, it can be said that the various exile destinations of the Bishops of Constantinople serve as a perfect illustration of the fact that the sea routes functioned as the most rapid and convenient means of communication in the Roman Empire, while the journey by land was much more time-consuming and made the traveller have to endure more difficulties and hardship.

\footnotetext{
${ }^{77}$ On Gemellus, see PLRE, vol. I, p. 388 (s.v. Gemellus 2). He served as Prefect of the City in the years 404-408.

${ }^{78}$ On Paianius, see PLRE, vol. II, p. 818 (s.v. Paianius). Paianius is a figure attested as Prefect of the City in 404.

${ }^{79}$ Cf. the edition of John's letters: $P G$, vol. 52, cols. 549-748.

${ }^{80}$ La lettre de Nestorius aux habitants de Constantinople, ed. E.W. Brooks, ROC 15, 1910, p. 275-281.
} 


\section{Bibliography}

\section{Sources}

Athanasius, Werke, vol. II, 1, Die Apologien, ed. H.G. Opitz, Berlin-Leipzig 1935-1941.

Callinicos, Vie d' Hypatios, ed. et trans. G.J.M. Bartelink, Paris 1971.

The Chronicle of Marcellinus, trans. B. СRокE, Sydney 1995.

The Ecclesiastical History of Evagrius with the scholia, ed. J. Bidez, L. Parmentier, London 1898.

Georgii Monachi Chronicon, ed. C. DE BooR, vol. II, Textum genuinum inde a Vespasiani imperio continens, Lipsiae 1904.

Historia Ecclesiastica Zachariae Rhetori vulgo adscripta, ed. E.W. BrooKs, vol. II, Lovanii 1924.

John Chrysostom's Letters, [in:] PG, vol. LII, col. 549-748.

John of Ephesus, Lives of the Eastern Saints, Introduction, trans., ed. E.W. Brooks, PO XVIII, Paris 1924.

La lettre de Nestorius aux habitants de Constantinople, ed. E.W. Brooks, ROC 15, 1910, p. 275-281.

Liberatus, [in:] ACO, vol. II, Concilium Universale Chalcedonense, vol. V, Collectio sangermanensis, ed. E. Schwartz, Berolini et Lipsiae 1936, p. 98-141.

Nestoriana. Die Fragmente des Nestorius, ed. F. Loofs, Halle 1905.

Nestorius, Le livre d'Héraclide de Damas, ed. P. Bedjan, Paris 1910.

Palladios, Dialogue sur la vie de Jean Chrysostome, ed., trans. A.-M. Malingrey, Ph. Leclerce, vol. I, Paris 1988.

Philostorgius, Kirchengeschichte. Mit dem Leben des Lucian von Antiochien und den Fragmenten des arianischen Historiographen, ed. J. Bidez, F. Winkelmann, Berlin 1981.

Photius, Bibliothéque, ed., trans. R. Henry, vol. I, Paris 1959.

La seconde partie de l'histoire de Barhadbešabba 'Arbaïa et controverse de Théodore de Mopsueste avec les macédoniens, ed., trans. F. NAU, PO 9, Paris 1913, p. 493-677.

Socrates, Kirchengeschichte, ed. G.Ch. HANSEn, coll. M. Širinjan, Berlin 1995.

Sozomenus, Kirchengeschichte, ed. J. Bidez, G.Ch. Hansen, Berlin 1960.

The Synodicon Vetus, ed., trans. J. Duffy, J. PARKer, Washington 1979.

Theodoret, Kirchengeschichte, ed. L. Parmentier, F. Scheidweiler, Berlin 1954.

Theodoros Anagnostes, Kirchengeschichte, ed. G. Ch. Hansen, Berlin 1971.

Theophanis Chronographia, rec. C. DE Boor, vol. I, Lipsiae 1883.

Vie de Sévère par Jean, superieur de monástere de Beith-Aphthonia, ed. M.-A. Kugener, PO 2, Paris 1907, p. 203-400.

Vittore da Tunnuna, Chronica. Chiesa e impero nell'età di Giustiniano, ed. A. Placanica, Firenze 1997.

\section{Secondary Literature}

BALl J., Khargah Oasis. Its Topography and Geology, Cairo 1900.

Barnes T.D., Athanasius and Constantius. Theology and Politics in the Constantinian Empire, Cambridge 1993. 
Baur Chr., Der heilige Johannes Chrysostomus und seine Zeit, vol. I-II, München 1929-1930.

BenZinger I., Emesa, [in:] RE, vol. V, Stuttgart 1905, col. 2496-2497.

van Berchem D., Recherches sur la chronologie de Syrie et de Mésopotamie, Sy 31, 1954, p. 265-267.

Bevan G.A., The Case of Nestorius: Ecclesiastical Politics in the East, 428-451 CE. A thesis submitted in conformity with the requirements for the Degree of Doctor of Philosophy Graduate Department of Classics, in the University of Toronto, Toronto 2005.

Bevan G.A., The Last Days of Nestorius in the Syriac Sources, JCSSS 7, 2007, p. 39-54.

Blaudeau Ph., Alexandrie et Constantinople (451-491). De l'histoire à la géo-ecclésiologie, Roma 2006.

BürCHNER, Hypaipa, [in:] RE, vol. VIII, Stuttgart 1914, col. 195-196.

Chadwick H., The Exile and Death of Flavian of Constantinople. A Prologue to the Council of Chalcedon, JTS 6, 1955, p. 17-34.

Dagron G., Naissance d’une capitale, Constantinople et ses institutions de 330 à 451, Paris 1974.

Delmaire R., Exil, rélegation, déportation dans la législation du bas-empire, [in:] Exil et rélegation. Les tribulations du sage et du saint durant l'Antiquité romaine et chrétienne (IIr-IV s. ap. J.-C.), ed. Ph. Blaudeau, Paris 2008, p. 115-132.

Diehl E., Pityus, [in:] RE, vol. XX, Stuttgart 1950, col. 1883-1884.

Drinkwater J.F., The revolt and ethnic origin of the usurper Magnentius (350-53) and the rebellion of Vetranio (350), Chi 30, 2000, p. 131-159.

FilipCZaK P., Bunty i niepokoje w miastach wczesnego Bizancjum (IV wiek n.e.), Łódź 2009.

Foss C., Amaseia, [in:] ODB, p. 74.

Foss C., Ankyra, [in:] ODB, p. 102.

Foss C., Euchaita, [in:] ODB, p. 737.

Foss C., Gangra, [in:] ODB, p. 821.

Fournier E., Exiled Bishops in the Christian Empire: Victims of Imperial Violence?, [in:] Violence in Late Antiquity: Perception and Practices, ed. H. Drake, Aldershot 2006, p. 157-166.

Frend W.H.C., The Fall of Macedonius in 511 - a Suggestion, [in:] Kerygma und Logos. Beiträge zu den geistesgeschichtlichen Bezeihungen zwischen Antike und Christentum. Festschrift für Carl Andresen zum 70. Geburtstag, ed. A.M. RitTER, Göttingen 1979, p. 183-195.

GrÉgolre H., Géographie byzantine, BZ 19, 1913, p. 59-61.

Grillmeier A. in collaboration with Hainthaler Th., Christ in Christian Tradition, vol. II, From the Council of Chalcedon (451) to Gregory the Great (590-604), pars II, The Church of Constantinople in the sixth century, transl. J. CAWTE, P. Allen, London 1995.

HaArer F.K., Anastasius I. Politics and Empire in the Late Roman World, Cambridge 2006.

de Halleux A., La première session du concile d'Éphèse (22 juin 431), ETL 69, 1993, p. 48-87.

Hillner J., Confined Exiles: An Aspect of the Late Antique Prison System, Mil 10, 2013, p. 385-434.

Hillner J., Prison, Punishment and Penance in Late Antiquity, Cambridge 2015.

Honigmann E., Anthimus of Trebizond, Patriarch of Constantinople (June 535-March 536), [in:] Patristic Studies, Città del Vaticano 1953, p. 185-193.

ILSKI K., Sobory w polityce religijnej Teodozjusza II, Poznań 1992.

Janin R., Eutichio, [in:] Bibliotheca Sanctorum, vol. V, Roma 1964, col. 323-324

Kaegi W.E., Kazhdan A., Petra, [in:] ODB, p. 1642-1643.

Kazhdan A., Eutychios, [in:] ODB, p. 759 
Kelly J.N.D., Golden Mouth. The Story of John Chrysostom. Ascetic, Preacher, Bishop, New York 1995. Kosıńsкi R., Dzieje Akacjusza, patriarchy Konstantynopola w latach 471-489, USS 9, 2010, p. 63-97.

KosıŃski R., Dzieje Nestoriusza, biskupa Konstantynopola w latach 428-431, [in:] U schyłku starożytności. Studia źródłoznawcze, vol. VII, ed. P. JAniszewski, R. Wiśniewski, Warszawa 2008, p. 30-63.

Kosı́́sкi R., Euphemios, Patriarch of Constantinople in the Years 490-496, JÖB 62, 2012, p. 57-79.

LeszKa M.B., Kościót i jego wpływ na życie mieszkańców Konstantynopola, [in:] Konstantynopol - Nowy Rzym. Miasto i ludzie w okresie wczesnobizantyńskim, ed. M.J. LeszKa, T. Wolińska, Warszawa 2011, p. 350-400.

Luibheid C., The Arianism of Eusebius of Nikomedia, ITQ 43, 1976, p. 3-23.

Mango M.M., Emesa, [in:] ODB, p. 690.

McGuckin J., Saint Cyril of Alexandria and the Christological Controversy. Its History, Theology, and Texts, New York 2004.

MiLEwski I., Depozycje i zsyłki biskupów w Cesarstwie Wschodniorzymskim (lata 325-451), Gdańsk 2008.

OAtes D., Studies in the Ancient History of Northern Iraq, Oxford 1968.

Oberhummer E., Beroia, [in:] RE, Bd. III, Stuttgart 1897, col. 304-306.

Ruge, Kokusos, [in:] RE, vol. VI, Stuttgart 1921, col. 1065.

Schwartz E., Publizistische Sammlungen zum acacianischen Schisma, München 1934.

Simonetti M., La crisi ariana nel IV secolo, Roma 1975.

Spycha£A D., Cesarze rzymscy a arianizm od Konstantyna Wielkiego do Teodozjusza Wielkiego (312-395), Poznań 2007.

Spychąa D., Saint Paul et Macedonius ou la lutte pour le thrône de l'évêque de Constantinople sous le règne de Constance II, [in:] Studia Lesco Mrozewicz ab amicis et discipulis dedicata, ed. S. Ruciński, C. Balbuza, Ch. KrólczyK, Poznań 2011, p. 377-390.

TAFler W., Paul of Constantinople, HTR 43, 1950, p. 30-92.

Tiersch C., Johannes Chrysostomus in Konstantinopel (398-404). Weltsicht und Wirken eines Bischofs in der Hauptstadt des Oströmischen Reiches, Tübingen 2002.

Weissbach F.H., Singara, [in:] RE, s. II, Bd. III, Stuttgart 1927, col. 232-233.

Whitby M., Eutychius, Patriarch of Constantinople. An Epic Holy Man, [in:] Homo Viator: Classical Essays for John Bramble, ed. M. Whitby, Рн. Hardie and M. Whitby, Bristol 1987, p. 297-308.

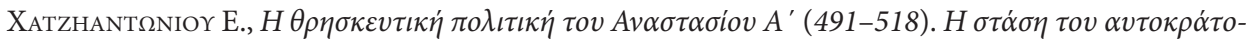

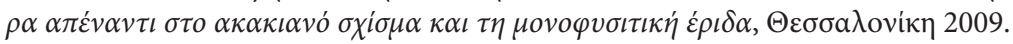

\footnotetext{
Abstract. A number of cases of the bishops of Constantinople exiled over a period until as late as the close of the $6^{\text {th }}$ century prove the fact that the rulers would always make an effort to remove the deposed bishops from the City, even though relocating the latter to specific destinations did not always have to be the case. In the $4^{\text {th }}$ century, the bishops could withdraw to suburban districts or settle at their own estates, and it was not until the $5^{\text {th }}$ century that depositions of the metropolitan bishops would involve, in principle, being deported to a specific place of exile. The purpose behind banishing a bishop from the City and putting him under supervision at a certain location was to prevent him from exerting any influence on the faithful in Constantinople.
} 
It should be also noted that sending a person into exile was a form of punishment, especially when the destination was a remote location exposed to harsh weather conditions or the threat of sudden incursions by bands of nomads or brigands. Results of an analysis of the accessibility of exile destinations provide substantial evidence for an overwhelming proportion of inland urban localities. Although many of such places would be located along or near various roads, they were generally situated far from the coast or the main routes to Constantinople.

Keywords: Byzantium, Byzantine Church, bishops of Constantinople (4-6 c.)

Rafał Kosiński

Uniwersytet w Białymstoku, Wydział Historyczno-Socjologiczny, Instytut Historii i Nauk Politycznych Zakład Historii Starożytnej i Bizancjum

Plac Uniwersytecki 1 15-420 Białystok, Polska/Poland rkosiu@interia.pl 


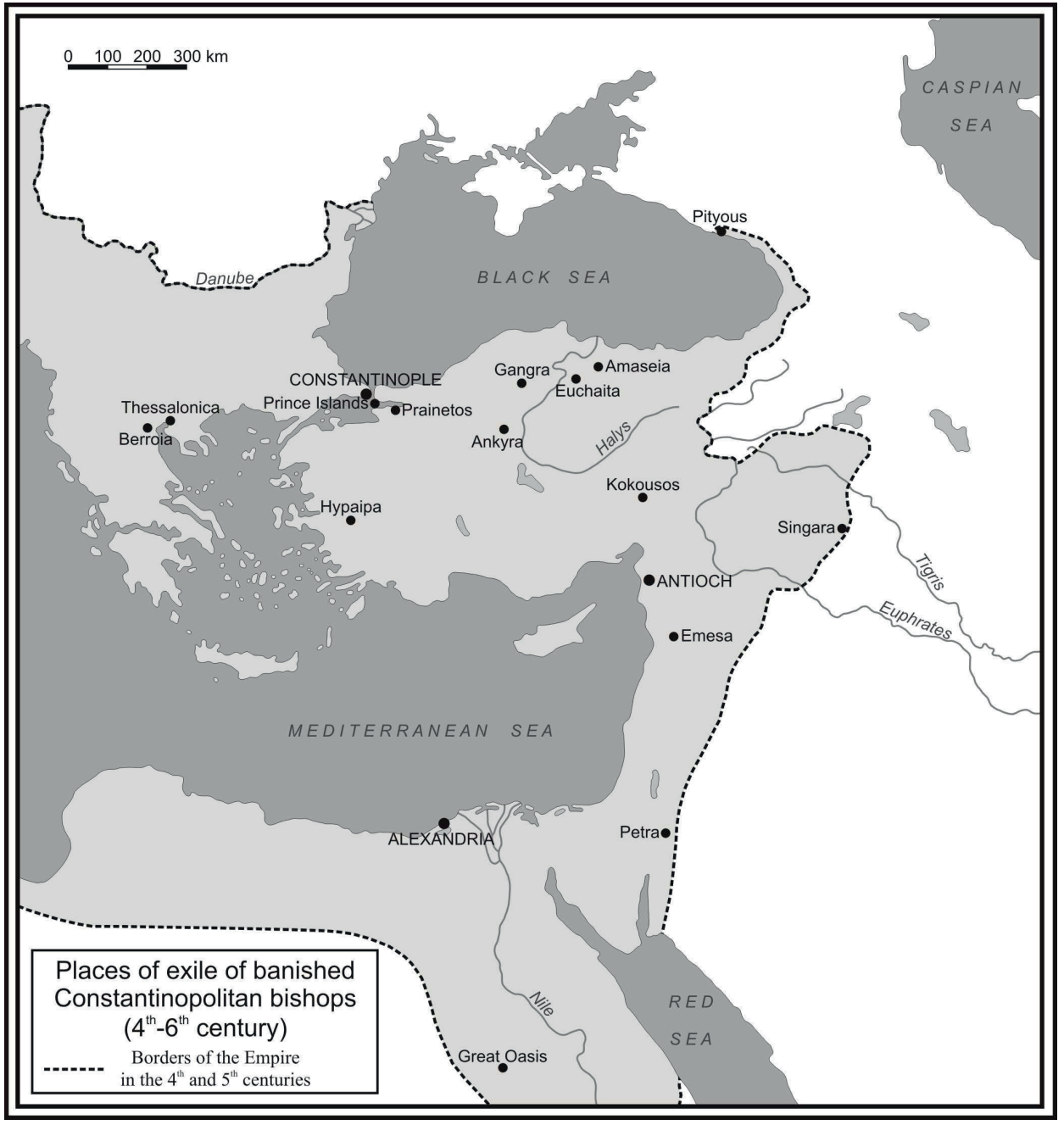

